\title{
Naskah Naskah Kuno Di Provinsi Jambi Sebagai Sumber Arkeologi
}

\author{
Yusdi Andra \\ Program Studi Arkeologi FIB Universitas Jambi \\ email: yusdiandra@yahoo.com
}

\begin{abstract}
Searching for the Malay kingdom which is related to the manuscripts originated mostly from Chinese records which is evidenced that Jambi Malay ever triumphed and connected to Tiongkok in the past. Other data that can support the manuscripts of the ancient of Jambi Malay in classical times, in Jambi Malay land the government system was carried out from generation to generation in a royal family which was respected by the wider community. Almost all the Malay manuscripts were written in Jawi letters (the Malay letters = the Bald Arabic letters), could be predicted that the writing of Malay manuscripts were started around 14th century. Meanwhile the previous Malay manuscripts were written in Jawi letters, and were suspected before Islam came to Indonesia. By finding Tanjung Tanah manuscript proved that Malay people had pre-Islamic manuscript tradition. In that era, the manuscripts were also written on the bark, reed, palm leaf, and horn. Generally, the manuscripts contain the local chronics, tradition, religion, correspondences, king's documents, languages and arts, tasauf / philosophy, education and even medicines. If we see from the writing, it is clear that the substitution of the writing that from oral tradition to written tradition. Jambi province has many interesting goods, related to the ancient manuscripts which were only a small portions that had been recorded and saved in the museum. While the most part portions still saved by the people. The result of the research showed the manuscript elements I; (1) Kerinci was under controlled by Jambi kingdom at that time, (2) Islam could not be accepted generally and Syari'a law in Kerinci land did not work well. Manuscript element II (1) the emptiness position as a king in Jambi, the coming of Princess Selaras Pinang Masak became a king in Ujung Jabung, the story of Ahmad Salim from Sultan Turki's descendent whose ship broke up and stranded in Berhala island, and the story of Ahmad Salim's wedding titled Datuk Paduko Berhalo with Princess Selaras Pinang Masak was the beginning of the growth of Islam in Jambi. Manuscript element III (1) Orang Kayo Hitam was the youngest child of Princess Selaras Pinang Masak with Datuk Paduko Berhalo, he graced much the story of Jambi from the beginning of Islam era that grew in Jambi. When he was adult, he saw the suffering of his people collecting funds to be offered to Mataram kingdom as a tribute. In this case, Orang Kayo Hitam did not agree what his people did, (2) Orang Kayo Hitam wished to be killed, but the plan of King Mataram had been known by Orang Kayo Hitam, so he went alone to Java island to see the situation and would take back the Keris itself from King Mataram's hand. He disguised himself as he arrived in Java island and after learning its condition, with all of his ingenuities, Orang Kayo Hitam could know the place of where the Keris made. He killed the blacksmith and took that Keris, (3) King Mataram asked for peace, as a sign of the friendship of Orang Kayo Hitam whom married with one of his princess that is Ratumas Pemalang. Orang Kayo Hitam brought along that Keris in his hand, that was also announced that Keris named Keris Siginjai. Manuscript element IV; (1) Orang Kayo Hitam in his married with Ratumas Pemalang had four children, they were Penambahan Ratu Kapas, Penambahan Rengas Pandak, Penambahan Bawah Sawo, and Penambahan Kota Baru, (2) in Sahibul Hikayat / Sahibul Saga, they used Panambahan as their title, where the title was usually used by the kingdom of Mataram. The use of the name was because there was a marriage relationship between Orang Kayo Hitam with Ratumas Pemalang, a daughter of King Mataram.
\end{abstract}

Key Words : Ancient Manuscripts as an archeological source.

Abstrak: Mencari kerajaan Melayu yang terkait dengan manuskrip sebagian besar berasal dari catatan Cina yang dibuktikan bahwa Melayu Jambi pernah menang dan terhubung ke Tiongkok di masa lalu. Data lain yang dapat mendukung naskah kuno Melayu Jambi di zaman klasik, di tanah Melayu Jambi sistem pemerintahan dilakukan dari generasi ke generasi dalam keluarga kerajaan yang dihormati oleh masyarakat luas. Hampir semua manuskrip Melayu ditulis dalam huruf Jawi (huruf Melayu = huruf Arab Botak), dapat diprediksi bahwa penulisan manuskrip Melayu dimulai sekitar abad ke-14. Sementara itu manuskrip Melayu sebelumnya ditulis dalam huruf Jawi, dan diduga sebelum Islam datang ke Indonesia. Dengan menemukan manuskrip Tanjung Tanah terbukti bahwa orang Melayu memiliki tradisi manuskrip pra-Islam. Di era itu, naskah juga ditulis di kulit kayu, buluh, daun palem, dan tanduk. Secara umum, naskah berisi chronik lokal, tradisi, agama, korespondensi, dokumen raja, bahasa dan seni, tasauf / filsafat, pendidikan dan bahkan obat-obatan. Jika kita melihat dari tulisannya, jelaslah bahwa substitusi tulisan itu dari tradisi lisan ke tradisi tertulis. Provinsi Jambi memiliki banyak barang menarik, terkait dengan naskah kuno yang hanya sebagian kecil yang telah dicatat dan disimpan di museum. Sementara sebagian besar porsi masih diselamatkan oleh rakyat. Hasil penelitian menunjukkan elemen manuskrip I; (1) Kerinci berada di bawah kendali kerajaan Jambi pada waktu itu, (2) Islam tidak dapat diterima secara umum dan hukum Syari'ah di tanah Kerinci tidak berfungsi dengan baik. Naskah elemen II (1) posisi kekosongan sebagai raja di Jambi, kedatangan Putri Selaras Pinang Masak menjadi raja di Ujung Jabung, kisah Ahmad Salim dari keturunan Sultan Turki yang kapalnya pecah dan terdampar di pulau Berhala, dan kisah pernikahan Ahmad Salim yang berjudul Datuk Paduko Berhalo dengan Putri Selaras Pinang Masak adalah awal dari pertumbuhan Islam di Jambi. Naskah elemen III (1) Orang Kayo Hitam adalah anak bungsu dari Putri Selaras Pinang Masak dengan Datuk Paduko Berhalo, ia banyak menyemarakkan kisah Jambi dari awal era Islam yang tumbuh di Jambi. Ketika dia dewasa, dia melihat penderitaan rakyatnya mengumpulkan dana untuk ditawarkan ke kerajaan Mataram sebagai upeti. Dalam hal ini, Orang Kayo Hitam tidak setuju dengan apa yang dilakukan rakyatnya, (2) Orang Kayo Hitam ingin dibunuh, tetapi rencana Raja Mataram telah diketahui oleh Orang Kayo Hitam, jadi ia pergi sendiri ke pulau Jawa untuk melihat situasi dan akan mengambil kembali Keris itu sendiri dari tangan Raja Mataram. Dia 
menyamar ketika tiba di pulau Jawa dan setelah mengetahui kondisinya, dengan semua kecerdikannya, Orang Kayo Hitam bisa mengetahui tempat pembuatan keris. Dia membunuh pandai besi dan mengambil Keris itu, (3) Raja Mataram meminta perdamaian, sebagai tanda persahabatan Orang Kayo Hitam yang menikah dengan salah satu puterinya yaitu Ratumas Pemalang. Orang Kayo Hitam membawa Keris itu ke tangannya, yang juga mengumumkan bahwa Keris bernama Keris Siginjai. Manuskrip elemen IV; (1) Orang Kayo Hitam dalam pernikahannya dengan Ratumas Pemalang memiliki empat anak, mereka Penambahan Ratu Kapas, Penambahan Rengas Pandak, Penambahan Bawah Sawo, dan Penambahan Kota Baru, (2) di Sahibul Hikayat / Sahibul Saga, mereka menggunakan Panambahan sebagai anak mereka. judul, di mana gelar itu biasanya digunakan oleh kerajaan Mataram. Penggunaan nama itu karena ada hubungan pernikahan antara Orang Kayo Hitam dengan Ratumas Pemalang, seorang putri Raja Mataram.

Kata Kunci: Naskah Kuno sebagai sumber arkeologis.

\section{PENDAHULUAN}

Provinsi Jambi sejak ratusan tahun yang lampau telah dihuni oleh bangsa melayu yang berasal dari Ras Mongoloid. Memasuki wilayah pantai dan pedalaman Jambi antara tahun 2000 SM sampai tahun 500 SM. Naskah tertua kerajaan melayu berasal dari Tang-hui-yeu yang ditulis oleh Wang-pu tahun 961 M. Pada masa dinasti Tang tahun 618-907 M, menurut sumber tersebut tersebut kerajaan Me-lo-yeu (Melayu) pernah mengirimkan utusan ke negeri Cina tahun 644 dan 645.

Menurut Soekmono dalam Yusdi(1992: 23 ) di dalam menelusuri kerajaan Melayu yang berkaitan tentang naskah banyak bersumber dari catatan Cina yang memberi petunjuk bahwa Melayu Jambi pernah berjaya dan berhubungan dengan Tiongkok pada masa lalu. Data lain yang dapat mendukung adalah naskah naskah kuno raja raja Melayu Jambi pada zaman klasik, bahwa dinegeri Melayu Jambi sistem pemerintahan dilakukan secara turun temurun dalam satu keluarga kerajaan yang dihormati oleh masyarakat luas.

Menurut Budihardjo (1997: 30) pengetahuan kita tentang naskah-naskah Melayu kuno sebagian besar tergantung dari naskah-naskah Melayu yang telah disalin atau ditulis sekitar abad ke 14 sampai ke 19. Selain naskah-naskah yang berhasil kita selamatkan dewasa ini sebenarnya banyak sekali nasakah-naskah lama yang musnah karena tidak dipelihara dengan baik. Misalnya karangan Raja Ali Haji yang dikutif oleh Tukfat al-Hafis dan naskah-naskah periode Kesultanan Pasai, Palembang, Malaka, Aceh, Jambi dan sebagainya. Bahkan ada naskah-naskah yang sengaja dihancurkan seperti yang terjadi di Aceh pada abad ke 17 yaitu karya-karya Syamsuddin dari Pasai, karena adanya kontradiksi yang melibatkan Nuruddin A Raniri.

Hampir semua naskah yang sekarang dipelihara di Inggris, Belanda, Swedia, Malaysia dan Indonesia hanya sebagian kecil, sebenarnya yang dihasilkan merupakan produk-produk akhir dari tradisi panjang pengaliran dan pengisahan kembali mulai abad ke 14 yang ditulis dengan huruf jawi atau Arab Melayu. Lebih lanjut dikatakan Budihardjo (1997: 30) tentang riwayat raja-raja Pasai yang semula dianggap naskah Melayu yang paling tua dibuat di Istana Pasai pada abad ke 14. Di ketahui hanya dari sebuah salinan yang dibuat untuk Sir Stamfard Raffles pada tahun 1815. Menurut Brakkel dalam Budihardjo (1997: 31) naskah hikayat melayu yang paling tua yang disimpan di berbagai lembaga Inggris berumur tidak lebih tua dari akhir abad ke 16. penyebaran naskah-naskah melayu ke seantero wilayah Eropa sebenarnya kurang dapat diketahui secara pasti, tetapi ada sebuah data yang menyatakan bahwa sewaktu Raffles selesai menjalankan tugasnya di Indonesia. Ia membawa banyak dokumen-dokumen dan selanjutnya tersebar di Eropa. Hampir semua naskah Melayu ditulis dengan huruf jawi (Arab melayu =Arab Gundul), dapat diperkirakan bahwa penulisan naskah melayu tentunya bermula pada sekitar abad 14.

Menurut Uli Kozok (2006: xii) naskah melayu yang sebelumnya ditulis dengan huruf Jawi, dan diduga sebelum Islam masuk ke Indonesia ada tradisi pernaskahan Melayu. Lebih lanjut dikatakan Uli Kozok dengan ditemuakannya naskah Tanjung Tanah membuktikan bahwa orang Melayu memiliki tradisi naskah pra-Islam. Demikian juga Naskah tanjung tanah abad ke 14 yang menggunakan kulit kayu sebagai media tulis ditegaskan Uli Kozok (2006: xiii) bahwa pada zaman itu naskah naskah juga ditulis pada buluh, daun palem dan tanduk.

Lebih lanjut menurut Budihardjo (1997: 30) umumnya isi naskah berisi kronik lokal, adat istiadat, agama, surat menyurat (wasiat), dokumen raja (Penguasa), bahasa (seni), tasauf, pendidikan (filsafat) dan bahkan obat-obatan. Dilihat dari penulisan nampak sekali peralihan dari penulisan tradisi lisan ke tradisi tulis. Hal ini dilihat dari adanya unsur-unsur yang irasional (bagi tasauf, filsafat dan sejenisnya). Kesemuanya itu termasuk aset budaya di Indonesia, dan naskah-naskah melayu yang berada di wilayah Propinsi Jambi masih banyak yang belum terungkap. 
Provinsi Jambi merupakan salah satu Provinsi di pulau Sumatra yang memiliki potensi budaya yang sangat menarik. Salah satu peninggalan budaya yang ada di Provinsi Jambi adalah candi Muara Jambi yang terluas di Asia Tenggara. Juga naskah naskah kuno (manuskrip). Berkaitan dengan naskah kuno di Provinsi Jambi dari sekian banyak naskah, hanya sebahagian kecil saja yang sudah tercatat dan tersimpan di museum. Sedangkan sebagian besar masih tersimpan olah masyarakat.

Laporan penelitian naskah-naskah kuno di Provinsi Jambi masih banyak yang belum terungkap. Karena penelitian tentang naskah di Provinsi Jambi sangat terbatas. Disisi lain banyak naskah naskah kuno yang dimiliki masyarakat tidak mau diserahkan kepada pemerintah untuk diteliti atau dimiliki. Pemilik naskah beranggapan tidak boleh dimiliki pemerintah, karena naskah naskah itu adalah warisan. Akhirnya banyak naskah-naskah yang dimiliki akhli waris tidak bisa diselamatkan, karena termakan usia dan tidak terawat dengan baik.

Naskah Melayu yang sampai sekarang dianggap naskah Melayu tertua adalah dua surat berhuruf Jawi bertanggal tahun 1521 dan 1522 M, yang ditulis oleh Sultan Abu Hayat dari Ternate kepada raja Portugal. Kedua surat tersebut hanya dapat bertahan selama hampir lima ratus tahun, karena disimpan dalam arsif nasional Portugas di Lisabon. Kedua naskah surat Sultan Ternate tersebut masih tersimpan dengan baik di arsif nasional Portugas di Lisabon ( Uli Kozok 2006: 43).

Dijelaskan lebih lanjut oleh Uli Kozok (2006: 44) bahwa naskah atau barang pusaka Kerinci selalu disimpan di loteng rumah, dan jarang sekali diturunkan. Penyimpanannya juga tidak sembarangan. Semua barang pusaka pada umumnya dibalut dengan kain dan disimpan disebuah peti kayu yang sangat kokoh. Bila disimpan dengan cara itu maka pusaka itu terlindung dari dari sinar matahari yang bias merusak naskah naskah tersebut.

Menurut Ali Rachman (2006: 2) masyarakat Melayu pada umumnya masih memegang teguh pada adat yang bersendikan syarak yang merupakan kristalisasi antara sistem sosial dan sistem ekologi. Penghormatan terhadap benda pusaka pada masyarakt Melayu sangat dijunjung tinggi. Kehidupan sehari hari masyarakat Melayu dalam sejarah terhimpun dalam tamaddun. Peninggalan naskah yang ada telah dapat mengungkap, bahwa masyarakat Melayu di Provinsi Jambi pernah berada dalam sejarah sebagai kerajaan yang memegang kendali kawasan pantai timur Sumatra.

Berdasarkan uraian diatas maka peneliti dapat memfokuskan pada kegiatan pelestarian naskah mengingat beberapa hal sebagai berikut: 1) Hampir semua naskah-naskah yang berada di wilayah Provinsi Jambi belum dapat disingkap mengenai kandungan isinya. 2) Kondisi naskah-naskah kuno yang terdiri dari bahan kertas terbatas umurnya, sehingga lama-lama akan hancur dan musnah. 3) Pandangan masyarakat yang sifatnya tradisionil harus secara bertahap dapat dihilangkan agar naskah dapat diselamatkan.

\section{Tinjauan Pustaka}

Naskah sebenarnya merupakan salah satu objek kegiatan filologi. Menurut Skipley dalam Budihardjo (1997: 31) mengatakan secra etimologi kata filologi berasald ari kata Yunani "Philos" yang berarti cerita dan "logos" yang berarti kata. Jadi cerita kata atau senang bertutur. Arti ini kemudian berkembang menjadi senang belajar, lebih mendalam dapat dikatakan bahwa filologi adalah mengkaji teks-teks lama secara mendalam terhadap bahasan, tulisan maupun terhadap aspek kebudayaan yang melatar belakanginya dari berbagai macam segi kehidupan pada masa lampau, dengan segala aspeknya yang dapat diketahui secara eksplisit melalui naskah.

Selanjutnya Nafran Hasyim dalam Budihardjo (1997: 32) mengatakan bahwa filologi memandang perbedaan yang ada dalam berbagai naskah sebagai suatu ciptaan dan menitik beratkan kerjanya pada perbedaan-perbedaan tersebut serta memandangnya justru konservatif yang positif. Dalam perkembangan selanjutnya arkeologi dan sejarah kebudayaan di Nusantara filologi banyak dipengaruhi oleh bangsa Belanda yang mempunyai pengertian disiplin yang berbeda berdasarkan kerja pada bahan tertulis. Disisi lain bertujuan mengungkapkan makna teks tersebut dalam segi kebudayaan. Lebih lanjut dikatakan Budihardjo (1997) filologi di Indonesia diterapkan pada teks-teks yang mengungkapkan bahasa Aceh, Batak, Minangkabau, Melayu, Jawa dan sebagainya. Dalam kaitannya dengan penelitian naskah menunjukkan pengertian yang abstrak, sedangkan naskah merupakan suatu yang konkrit. Oleh karena itu pemahaman terhadap teks klasik hanya dapat dilakukan lewat naskah.

Menurut Muhammad Bahrudin (2011) dalam Yusuf (1982:2) naskah adalah tulisan tangan yang belum dicetak atau diterbitkan. Lebih lanjut dikatakan Muhammad Bahrudin (2011) dalam Feater (1997: 
289) mendefinisikan yaitu: Manuskrif adalah dokumin dari berbagai jenis yang ditulis dengan tangan, tetapi lebih mengkhususkan kepada bentuk yang asli sebelum dicetak. Kata tersebut juga bisa berarti karangan, surat, dsb yang masih ditulis dengan tangan.

Selanjutnya Undang- Undang Cagar Budaya Npmor 5 Tahun 1992. Bab I pasal 2 menjelaskan bahwa naskah kuno atau manuskrif adalah dokumen dalam bentuk apapun yang ditulis dengan tangan atau diketik yang belum dicetak atau dijadikan buku tercetak yang berumur 50 tahun lebih.

Menurut Sukaesih et al (2016: 181) upaya pelestarian naskah kuno dapat dilakukan melalui dua cara yaitu cultural experience, yakni dengan cara terjun mempelajari naskah-naskah kuno untuk mengetahui dan memahami isi yang terdapat dalam naskah. Sehingga masyarakat mengetahui pesan moral yang terkandung dalam naskah kuno tersebut. Sedangkan cara kedua melalui cultural knowledge, yaitu dengan membuat pusat pusat kajian atau pusat informasi atau museum berfungsi untuk menyimpan dan memelihara naskah kuno.

Teks-teks filologi ada yang berupa teks lisan dan teks tulisan. Dalam hal ini kita mengenal filologi lisan, filologi naskah dan filologi cetakan. Naskah-naskah di Nusantara mengemukakan isi yang sangat kaya. Kekayaan itu dapat ditunjukkan dengan aneka ragam aspek kehidupan yang dikemukakan, misalnya masalah sosial, politik, ekonomi, agama, kebudayaan, bahasa dan sastra.

Menurut Oman Fathurahman kajian hasil budaya tulis asia tenggara atau nusantara sudah tidak terbantahkan lagi. Selanjutnya dikatakan Oman di Indonesia tradisi menulis masyarakat diwilayah asia tenggara bisa dilacak hingga berabad abad ke belakang sebelum kedatangan Islam dan sebelum Indonesia lahir. Kozok (2006) dalam Oman memberi contoh bahwa naskah tanjung tanah tinggalan melayu dan sansekerta, diduga kuat sebagai naskah melayu sisa yang tidak pernah ada naskah yang disimpan di daerah kerinci adalah kehadiran dari masa pra-Islam.

Lebih lanjut dikatakan Budihardjo (1997: 32) naskah yang menjadi sasaran kerja filologi dipandang sebagai hasil budaya yang berupa cipta sastra, karena teks yang ada di dalamnya yang merupakan suatu keutuhan dan mengungkapkan kesan. Pesan yang terbaca di dalam teks secara fungsional berhubungan erat dengan filsafat hidup dan dengan berbentuk kesenian yang lain. Dilihat dari kandungan maknanya wacana yang berupa teks klasik itu mengemuakakan fungsi tertentu, yaitu membayangkan fikiran dan membentuk watak yang berlaku, baik bagi orang yang sejaman maupun bagi generasi mendatang. Penyebutan "klasik" pada teks-teks sastra Nusantara hakekatnya berkenaan dengan masalah waktu. Dalam pengertian ilmu sastra klasik biasa disebut pramodern (periode pengaruh Eropa belum masuk secara intensif). Sebagai permasalahan lama, masalah waktu penciptaan naskah tidak dapat diketahui secara pasti karena dalam fisik naskah tidak dijumpai data-data waktu.

Menurut Bakar (1958) dalam Budihardjo (1997) derajat kesaksian dapat dibagi menjadi 3 (tiga) bagian yakni :

a. Derajat kesaksian tinggi, yakni berdasarkan atas sumber tertulis sejaman dan setempat, asli dan dalam negeri (sejarah).

b. Derajat kesakasian berdasarkan atas sumber tertulis sejaman, tetapi tidak setempat atau setempat tetapi tidak sejaman (proto sejarah).

c. Derajat kesaksian rendah yakni berdasarkan atas sumber tidak tertulis, baik sejaman, setempat, setempat tidak sejaman (pra sejarah).

Mempelajari sumber ilmu masa lalu disebut historiografi. Menurut sastra menyebutnya ilmu naskah. Sumber ilmu proto sejarah merupakan sasaran ilmu antrapologi, sedangkan sumber-sumber pra sejarah diselidiki oleh Archeologi. Oleh karena itu penelitian ini mengenai naskah sebagai sumber arkeologi perlu bantuan disiplin ilmu lain diantaranya filologi (lingustik dan ilmu sastra), sejarah kebudayaan, antropologi budaya, sosiologi, etnologi dan filsafat.

Berdasarkan uraian diatas dapat ditarik kesimpulan bahwa yang dimaksud naskah adalah tulisan tangan yang belum dicetak atau diterbitkan. Sedangkan manuskrif adalah dokomen dari berbagai jenis yang ditulis dengan tangan, tetapi lebih mengkhususkan kepada bentuk yang asli sebelum dicetak. Kata tersebut juga bisa berarti karangan surat yang masih ditulis dengan tangan.

Undang- Undang Cagar Budaya Npmor 5 Tahun 1992. Bab I pasal 2 menjelaskan bahwa naskah kuno atau manuskrif adalah dokumen dalam bentuk apapun yang ditulis dengan tangan atau diketik yang belum dicetak atau dijadikan buku tercetak yang berumur 50 tahun lebih. Sedangkan upaya pelestarian naskah kuno dapat dilakukan melalui dua cara yaitu cultural experience, yakni dengan cara terjun mempelajari Jurnal Ilmiah Dikdaya, 9(2), September 2019 
naskah-naskah kuno untuk mengetahui dan memahami isi yang terdapat dalam naskah. Sehingga masyarakat mengetahui pesan moral yang terkandung dalam naskah kuno tersebut. Cara kedua melalui cultural knowledge, yaitu dengan membuat pusat pusat kajian atau pusat informasi atau museum berfungsi untuk menyimpan dan memelihara naskah kuno.

\section{PEMBAHASAN NASKAH}

Dalam pembahasan ini di kemukakan isi naskah secara berurutan dari naskah (1) Tanjung Tanah, naskah (2) Putri Selaras Pinang Masak, Naskah (3) Orang Kayo Hitam dan terakhir Naskah (4) Orang Kayo Hitam menikah dengan Ratumas Pemalang putri Raja Mataram.

\section{Naskah 1}

"Pertama jikalau kematian jangan diarak dengan gendang, gong, serunai dan bedil dan kedua jangan laki-laki bercampur dengan perempuan bertauh nyanyi dan jangan bersalah dan memuja hantu dan syetan dan batu kayu dan barang sebagainya dan ketiga jangan menikahkan perempuan dengan tiada walinya. Keempat jangan makan minum yang haram dan barang sebagainya dari pada segala yang tiada diharuskan syarak. Hubaya-hubaya jangan dikerjakan".

Menurut Uli Kozok (2006: 53) naskah tersebut membuktikan pada saat itu Kerinci berada dibawah nauangan Kesultanan Jambi. Agama Islam ternyata belum diterima secara umum di Kerinci, sehingga dalam surat yang bertanggal 18.7.1778, sultan Jambi menyuruh orang Kerinci agar melaksanakan hukum syarak di dalam tanah Kerinci dengan memperhatikan empat perkara.

Selanjutnya dikemukakan Uli Kozok (2006: 53) dalam surat Pangeran Surakarta bertanggal 21.7.1778. Pangeran menghimbau Kepada para Depati “ mupakatlah kamu dengan segala...yang di dalam alam Kerinci mendirikan agama Rasul Allah salla ilahu' alaihi wasallam dan seboleh bolehnya buangkan kamu barang yang mungkir.(...) Adalah umur dunia ini tiadalah akan berapa lama lagi. Sebaik-baiknya kamu dirikan ugama yang sebenarnya".

Berdasarkan uraian pada naskah tersebut diatas dapat ditarik kesimpulan bahwa alam Kerinci berada dibawah pemerintahan Kesultanan Jambi. Karena naskah yang ditulis tahun 1778 kesultanan Jambi mengangkat sejumlah depati di alam Kerinci dan memberikan peraturan yang mengikat. Mengancam akan menghukum mati para pemberontak, penipu, peracun, penikam di malam hari dan pengecoh.

\section{Unsur Naskah:}

1. Pada waktu itu Kerinci berada di bawah kesultanan Jambi.

2. Agama Islam belum diterima secara umum.

3. Hukum syarak di dalam tanah Kerinci belum dijalankan dengan baik.

Dengan bukti-bukti tesebut diatas maka naskah tanjung tanah sangat erat sekali arkeologi klasik.

\section{Naskah II}

Kata sahibul hikayat bahwa" Sri Baginda Putri Selaras Pinang Masak adalah keturunan dari Raja Adityawarman dengan permaisurinya putri Ratna Mandi. Selanjutnya Putri Selaras Pinang Masak turun ke negeri Jambi membangun negeri di ujung jabung. Beberapa tahun setelah putri Salaras Pinang Masak menjadi Raja di ujung Jabung, kata sahubul hikayat" ada terdampar seorang asing dipulau berhala karena kapal yang ditumpanginya pecah di selatan Singkep. Orang itu rupanya datang dari Konstantinopel (Turki) dan orang itu anak Sultan Turki dari keturunan Sultan Zainal Abidin.”

Pada suatu hari orang Turki itu pergi mengunjungi Ujung Jabung, dalam kunjungan itu orang Turki itu memperkenalkan diri kepada Sri Baginda Putri Selaras Pinang Masak, bahwa ia adalah seorang bangsawan dari Turki yang mengalami pecah kapal dalam pelayarannya, serta memperlihatkan bedilnya yang khas Turki sebagai bukti. Tidak lama setelah pertemuan itu terjadilah perkawinan antara keduanya. Dimana Achmad Salim bangsa Turki tersebut diberi gelar Datuk Paduko Berhalo, yaitu nama pulau yang pertama kali di singgahinya di daerah itu. Semenjak itu Ujung Jabung yang menjadi ibu negeri kerajaan Melayu Jambi, dibawah kekuasaan Putri Selaras Pinang Masak dengan suaminya Achmad Salim disebut Datuk Paduka Berhala.

Dari perkawinan Putri Selaras Pinang Masak dengan Achmad Salim gelar Datuk Paduka Berhala mendapatkan anak empat orang yaitu: Orang Kayo Pingai, Orang Kayo Pedataran, Orang Kayu Gemuk, Orang Kayu Hitam.

\section{Unsur Naskah:}


1. Di negeri Jambi terjadi kekosongan raja, kedatangan Putri Selaras Pinang Masak menjadi raja di Ujung Jabung

2. Kisah Achmad Salim dari keturunan Sultan Turki yang kapalnya pecah terdampar dipulau berhala.

3. Kisah perkawinan Achmad Salim gelar datuk paduka berhalo dengan Putri Selaras Pinang Masak awal dari perkambangan Islam di negeri Jambi.

Dengan bukti-bukti tersebut maka isi naskah sangat erat hubungannya dengan arkeologi dan dapat di analisis berdasarkan konsep arkeologi klasik.

\section{Naskah III}

Orang Kayo Hitam adalah anak bungsu Putri Selaras Pinang Masak dengan Datuk Paduko Berhalo, dialah yang banyak menghiasi sejarah Jambi kurun pertama jaman Islam berkembang di Jambi. Masa remaja Orang Kayu Hitam banyak menjelajah pulau-pulau lain, ingin mengetahui keadaan sekitar kerajaan ibunya Putri Selaras Pinang Masak. Dalam sahibul hikayat setelah dewasa ia melihat penderitaan rakyatnya mengumpul dana untuk dipersembahkan kepada kerajaan Mataram sebagai upeti. Dalam hal ini Orang Kayu Hitam tidak setuju lagi dilaksanakan rakyatnya, dan diancam akan dibunuh siapa saja yang akan meneruskan upeti. Sehingga kedua orang tuanya tidak bisa berbuat banyak.

Raja Mataram mendengar berita itu, lalu melakukan tindakan.Al kisah Raja Mataram mengumpulkan ahli nujum dan para dukun sakti untuk membuat keris yang terdiri dari berbagai besi dari sembilan desa. Keri situ lalu disepuh sebanyak empat puluh kali, setiap hari keliwon sekali sepuh. Pandai besinya harus seorang pendekar, karena pendekar itulah yang akan berhadapan dengan Orang Kayo Hitam itu kelak. Keris itulah kata para ahli nujum dan dukun-dukun sakti yang akan membunuh Orang Kayo Hitam.

Rencana Raja Mataram ini sudah diketahui oleh Orang Kayo Hitam, sendirian ia berangkat ke Jawa untuk mengetahui keadaan dan akan merebut keris itu sendiri dari tangan Raja Mataram. Setibanya di Jawa ia menyamar diri, setelah diketahui seluk beluknya, dengan segala kecerdikannya Orang Kayo Hitam dapat menemui tempat pembuatan keris itu. Pandai besi tersebut dibunuhnya dan keris itu dirampasnya. Raja Mataram mengetahui kejadian itu dan memperhitungkan Orang Kayo Hitam tidak dapat dikalahkan. Raja Mataram minta berdamai al kisah sebagai tanda persahabatan Orang Kayo Hitam dikawinkan dengan salah seorang putrinya, yaitu putri Ratumas Pemalang. Orang Kayo Hitam dengan membawa keris yang ada ditangannya, pada saat itulah di umumkan bahwa keris yang berada ditangan Orang Kayo Hitam itu diberi nama Keris Siginjai.

Al kisah dalam sahubul hikayat, setelah beberapa lama sesudah perkawian itu Orang Kayu Hitam didampingi istrinya Putri Ratumas Pemalang, dengan membawa keris siginjai pulang ke Ujung Jabung disertai beberapa orang dari istana Mataram sebagai pengantar. Sewaktu rombongan ini sampai di Ujung Jabung, pemerintahan ini sedang dijalankan oleh seorang saudaranya yaitu Orang Kayu Pingai. Sebab ayahnya telah meninggal dunia selama kepergiannya ke Jawa, dan dikuburkan di Pualau Berhala. Ibunyapun sudah meninggal nam Al kisah setelah dewasa ia melihat penderitaan rakyatnya mengumpul dana untuk dipersembahkan kepada kerajaan Mataram sebagai upeti. Dalam hal ini Orang Kayu Hitam tidak setuju lagi dilaksanakan rakyatnya,un tidak diketahui, dalam sahibul hikayat tidak diketahui dimana dikuburkan.

\section{Unsur Naskah:}

1. Orang Kayo Hitam adalah anak bungsu Putri Selaras Pinang Masak dengan Datuk Paduko Berhalo, dialah yang banyak menghiasi sejarah Jambi kurun pertama jaman Islam berkembang di Jambi.

2. Setelah dewasa ia melihat penderitaan rakyatnya mengumpul dana untuk dipersembahkan kepada kerajaan Mataram sebagai upeti. Dalam hal ini Orang Kayu Hitam tidak setuju lagi yang dilaksanakan rakyatnya.

3. Orang Kayu Hitam mau dibunuh, namun rencana Raja Mataram ini sudah diketahui oleh Orang Kayo Hitam, sendirian ia berangkat ke Jawa untuk mengetahui keadaan dan akan merebut keris itu sendiri dari tangan Raja Mataram. Setibanya di Jawa ia menyamar diri, setelah diketahui seluk beluknya, dengan segala kecerdikannya Orang Kayo Hitam dapat menemui tempat pembuatan keris itu. Pandai besi tersebut dibunuhnya dan keris itu dirampasnya.

4. Raja Mataram minta berdamai al kisah sebagai tanda persahabatan Orang Kayo Hitam dikawinkan dengan salah seorang putrinya, yaitu putri Ratumas Pemalang. Orang Kayo Hitam dengan membawa keris yang ada ditangannya, pada saat itulah di umumkan bahwa keris yang berada ditangan Orang Kayo Hitam itu diberi nama Keris Siginjai. 
Dengan bukti-bukti tersebut maka isi naskah bisa menambah khasanah prodi arkeologi dan dapat di analisis berdasarkan konsep arkeologi klasik.

\section{Naskah IV}

Orang Kayu Hitam dari perkawinannya dengan Ratumas Pemalang mempunyai anak empat orang yaitu: Penambahan Ratu Kapas, Penambahan Rengas Pandak, Penambahan Bawah Sawo, Penambahan Kota Baru. Dalam sahibul hikayat Penambahan Rantau Kapas meninggal dan dikebumikan dirantau kapas Muara Tembesi 1540.

Kemudian pemerintahan diteruskan oleh saudaranya bertiga silih berganti, dan terakhir pemerintahan dipegang oleh Penambahan Kota Baru.

Dalam sahibul hikayat gelar yang mereka pakai penambahan dimana biasanya gelar itu dipakai oleh kerajaan Mataram. Pemakaian nama itu dikarenakan ada hubungan perkawinan Orang Kayo Hitam dengan Ratumas Pemalang putri Raja Mataram.

Dari hubungan perkawinan dengan Kerajaan Mataram pengaru Islam semakin berkembang luas. Selama satu abad kerajaan Jambi dibawah pemerintahan yang bergelar penembahan. Kerjasama antara tiga kerajaan Islam yaitu Mataram, Banten dan Jambi terlihat dari ikatan perdagangan yang semakin pesat.

Hubungan persahabatan dan persaudaraan yang diwarisi oleh Orang Kayu Hitam, adalah ikatan yang telah dirintis Dalam sahibul hikayat gelar yang mereka pakai penambahan dimana biasanya gelar itu dipakai oleh kerajaan Mataram. Pemakaian nama itu dikarenakan ada hubungan perkawinan Orang Kayo Hitam dengan Ratumas Pemalang putri Raja Mataram. semenjak dan sebelum jadi Raja Jambi.

\section{Unsur Naskah:}

1. Orang Kayu Hitam dari perkawinannya dengan Ratumas Pemalang mempunyai anak empat orang yaitu: Penambahan Ratu Kapas, Penambahan Rengas Pandak, Penambahan Bawah Sawo, Pena mbahan Kota Baru.

2. Dalam sahibul hikayat gelar yang mereka pakai penambahan, dimana biasanya gelar itu dipakai oleh kerajaan Mataram. Pemakaian nama itu dikarenakan ada hubungan perkawinan Orang Kayo Hitam dengan Ratumas Pemalang putri Raja Mataram.

Dengan bukti-bukti tersebut maka isi naskah bias menjadi bahan kajian arkeologi dan dapat di analisis berdasarkan konsep arkeologi klasik.

\section{SIMPULAN}

Berdasarkan uraian diatas maka dapat ditarik beberapa kasimpulan sebagai berikut:

1. Agama Islam ternyata belum diterima secara umum di Kerinci, sehingga dalam surat yang bertanggal 18.7.1778, sultan Jambi menyuruh orang Kerinci agar melaksanakan hukum syarak di dalam tanah Kerinci dengan memperhatikan empat perkara. "Pertama jikalau kematian jangan diarak dengan gendang, gong, serunai dan bedil dan kedua jangan laki-laki bercampur dengan perempuan bertauh nyanyi dan jangan bersalah dan memuja hantu dan syetan dan batu kayu dan barang sebagainya dan ketiga jangan menikahkan perempuan dengan tiada walinya. Keempat jangan makan minum yang haram dan barang sebagainya dari pada segala yang tiada diharuskan syarak. Hubaya-hubaya jangan dikerjakan".

2. Dalam sahibul hikayat bahwa" Sri Baginda Putri Selaras Pinang Masak adalah keturunan dari Raja Adityawarman dengan permaisurinya putri Ratna Mandi. Selanjutnya Putri Selaras Pinang Masak turun ke negeri Jambi membangun negeri di ujung jabung. Beberapa tahun setelah putri Salaras Pinang Masak menjadi Raja di ujung Jabung, di dalam sahubul hikayat" ada terdampar seorang asing dipulau berhala karena kapal yang ditumpanginya pecah di selatan Singkep. Orang itu rupanya datang dari Konstantinopel (Turki) dan orang itu anak Sultan Turki dari keturunan Sultan Zainal Abidin."

3. Orang Kayo Hitam adalah anak bungsu Putri Selaras Pinang Masak dengan Datuk Paduko Berhalo, dialah yang banyak menghiasi sejarah Jambi kurun pertama jaman Islam berkembang di Jambi. Masa remaja Orang Kayu Hitam banyak menjelajah pulau-pulau lain, ingin mengetahui keadaan sekitar kerajaan ibunya Putri Selaras Pinang Masak. Dalam sahibul hikayat setelah dewasa ia melihat penderitaan rakyatnya mengumpul dana untuk dipersembahkan kepada kerajaan Mataram sebagai upeti. Dalam hal ini Orang Kayu Hitam tidak setuju lagi dilaksanakan rakyatnya, dan diancam akan dibunuh siapa saja yang akan meneruskan upeti. Sehingga kedua orang tuanya tidak bisa berbuat banyak. 
4. Orang Kayu Hitam dari perkawinannya dengan Ratumas Pemalang mempunyai anak empat orang yaitu: Penambahan Ratu Kapas, Penambahan Rengas Pandak, Penambahan Bawah Sawo, Penambahan Kota Baru. Dalam sahibul hikayat Penambahan Rantau Kapas meninggal dan dikebumikan dirantau kapas Muara Tembesi 1540.

Kemudian pemerintahan diteruskan oleh saudaranya bertiga silih berganti, dan terakhir pemerintahan dipegang oleh Penambahan Kota Baru. Dalam sahibul hikayat gelar yang mereka pakai penambahan dimana biasanya gelar itu dipakai oleh kerajaan Mataram. Pemakaian nama itu dikarenakan ada hubungan perkawinan Orang Kayo Hitam dengan Ratumas Pemalang putri Raja Mataram.

Dari beberapa kesimpulan yang dihasilkan, maka dapat peneliti sarankan beberapa hal sebagai berikut:

1. Kepada pemerintah kiranya mengupayakan penyelamatan terhadap naskah-naskah Melayu Kuno Jambi yang kondisinya semakin memprihatinkan. Upaya pemerintah dapat melibatkan instansi terkait.

2. Pemerintah perlu memasyarakatkan nilai-nilai hulur yang terkandung dalam naskah-naskah kuno untuk kepentingan penelitian dan pendidikan.

3. Memasukkan dalam kurikulum muatan lokal baik SD, SLTP, SLTA dan kurikulum perguruan tinggi yang berkaitan tentang kearkeologian, untuk lebih mencintai budaya daerah sebagai puncak-puncak kebudayaan Nasional.

\section{DAFTAR PUSTAKA}

Anonim. 2001. Lembaga Adat Propinsi Jambi. Pokok-Pokok Adat Pucuk Jambi Sembilan

Lurah. Jambi: Lembaga Adat Propinsi Jambi.

1999. Metode penelitian Arkeologi. Pusat Penelitian Arkeologi Nasional. Departemen Pendidikan Nasional. Jakarta

Bahrudin, Muhammad. 2011. Strategi Preservasi Naskah Kuno Sebuah Kajian Ilmu Pengetahuan dan Khasanah Bangsa Indonesia. Diakses tanggal 20 Juli 2019.

Budihardjo. 1997. Naskah-Naskah Melayu Jambi Salah Satu Sumber Sejarah. Majalah Ilmiah Seni dan Budaya Volume 1 Nomor 1 Tahun 1997. ISSN 1410-4180.

Fathurahman, Oman. Digitalisasi Naskah Aceh dan Dampak Bagi Pengembangan Perpustakaan Digital Naskah Nusantara, https:// www. Academia, edu. Diakses 28 Juli 2018.

Sukaesih el al (2016). Preservasi Naskah Kuno Sebagai Upaya Pembangunan Knowledge Manajemen. Studi Kegiatan Preservasi Naskah Kuno Oleh Masyarakat Sebagai Upaya Pembangunan Knowledge. Volume 2 Nomor 2. Tahun 2016. ISSN 2442-5168. Record and Library Journal di akses tanggal 28 Juli 2019.

Rahman, Ali. 1997. Jambi Dan Kepariwisataan: Upaya Pemberdayaan Adat Dalam Tamaddun Melayu. Majalah Ilmiah Seni dan Budaya Volume 1 Nomor 1 Tahun 1997. ISSN 1410-4180. 